\section{Agreement questioned}

\section{Washington}

THE allegation that the US government has concealed the conitroversy about the discovery of the human immunodeficiency virus (HIV) is the latest to be levelled by John Crewdson of the Chicago Tribune in his continuing commentary on the AIDS controversy. The latest allegations have sparked calls to renegotiate a 1987 treaty in which the United States and France agreed to share credit for the breakthrough. But it is still not clear whether such a renegotiation is legally justified, or whether the latest details were already known to the signatories of the treaty.

Crewdson, who last November wrote a 50,000-word article alleging that Robert Gallo of the US National Cancer Institute (NCI) obtained the AIDS virus from Luc Montagnier of the French Institut Pasteur either by "accident or a theft", wrote a further article on 25 March alleging a US cover-up of the matter.

Quoting a 1985 memorandum from Peter Fischinger, then NCI associate director, to a top official in the department of Health and Human Services (HHS), Crewdson points to "misstatements and omissions" that he says could have deceived the French into agreeing to share the discovery. The document is one of the few that the National Institutes of Health (NIH), under which NCI falls, has refused to release to Freedom of Information Act requests. Although Crewdson does not reveal how he got the memorandum, informed sources say it was leaked by a former government official.

Comparing the Fischinger memo with the Gallo laboratory records and other documents, Crewdson concludes that the memorandum selectively chooses some facts and ignores others to make a stronger argument for Gallo's discovery of the AIDS virus. Because the disputed memorandum was an important part of the documentation that led the US Justice Department to conclude that Gallo had independently discovered the virus, Crewdson suggests that the US case did not accurately reflect the facts known at the time. The French, who had not seen the memorandum nor the documentation leading up to it, may have thought that the case for an independent Gallo discovery was stronger than it actually was, he says.

Lawyers for the Institut Pasteur say that the revelations could be grounds for renegotiating the treaty. Among the factors that will be considered is how much information had been withheld from the French in 1987. "Was Pasteur significantly misled at the time?" asks Ira Millstein of Weil, Gotshal \& Manges. He says the Pasteur lawyers are discussing the

But one member of the team that issue with NIH. negotiated the 1987 treaty believes that agreed that the $[\mathrm{NCI}]$ test kit was based on Institut Pasteur version of the virus]", says Robert Charrow, a lawyer who was then in the HHS general counsel's office. Because the signatories had already acknowledged that Gallo's work had incorporated Montagnier's virus, "By definition [the treaty] could not be renegotiated." He believes the Fischinger memorandum (which he has seen) adds nothing new.

Michael Astrue, HHS general counsel, says he is familiar with the allegations, but he would not comment on the possibility of renegotiating the treaty.

The congressional oversight and investigations subcommittee under Representative John Dingell (Democrat, Michigan), which has taken an active interest in the matter, has so far made no moves in reaction to the latest disclosures. With an NIH inquiry in progress (see Nature 343, 680,22 February 1990), Dingell is expected to wait for a report from the investigators before taking new action.

In response to a January letter from Dingell, NIH director William Raub outlined 14 specific allegations the agency's Office of Scientific Integrity was investigating. Raub said that attention would be focused on "questions about how many isolates [came] from AIDS patients and when this occurred" in Gallo's laboratory, and "questions about the $\mathrm{H}-9$ cell line used" in the laboratory.

Although Crewdson's account has earned surprising little press attention in the United States, the French press has been riveted. Montagnier has been quoted in Le Monde as appealing to Gallo to "at last accept the evidence" and admit the true source of the AIDS virus. Such statements may threaten the treaty as much as the Crewdson allegations.

Attached to the 1987 document is a 'scientific history' of the discovery of the AIDS virus (Nature 326, 435; 1987). And in the text of the treaty is a clause stating that Robert Gallo and Luc Montagnier agree not to "make nor publish any statement which would or could be construed as contradicting or compromising the integrity of the said scientific history". Pasteur lawyer Millstein says he "did not advise Montagnier to make those statements". Nevertheless, the contrary reactions from opposite sides of the Atlantic suggests that the debate may well intensify. As the NIH, with the help of a new 11-person committee selected by the National Academy of Science, continues its secret inquiry, one observer wryly notes "in Paris, they're rioting in the streets". G. Christopher Anderson there is no basis for a reevaluation. "It was information gleaned from LAV [the companies quit the IBA Washington

LAST week's resignation of Genetics Institute and Cetus Corporation from the Industrial Biotechnology Association (IBA), following shortly after the withdrawal of another member, the Upjohn Company, is seen as a major loss to the association. Both companies to leave last week were founding members of the IBA in 1981 and are prominent in the industry. In a letter to Richard Godown, president of the IBA, Robert Fildes, president and chief executive officer of Cetus, stated that "the IBA has too frequently become the mouthpiece for a few companies whose positions do not represent those of all the members". The final straw seems to have been a vote taken by board members on 21 February to oppose changes in the 1983 Orphan Drug Act, as well as to support a bill now before a House of Representatives subcommittee, which proposes to strengthen US patent protection for genetically engineered products against unfair foreign competition.

The vote was unanimous, although neither Gabriel Schmergel, chief executive officer of Genetics Institute, or Fildes of Cetus, were present because of prior commitments. Both companies support changes to the act and are opposed to the proposed patent legislation. In a joint statement, they said that the act stands to "perpetuate or create market monopolies for highly profitable products such as recombinant human growth hormone and erythropoietin", two products with orphan drug status. Katharine Russell of Cetus says "to see the trade association take an anti-competitive position" on these matters is "lamentable".

The Orphan Drug Act was designed to provide tax incentives and a seven-year marketing monopoly in the United States to companies developing drugs for rare diseases affecting fewer than 200,000 patients.

Also at issue is the 'Boucher bill', introduced last month by Representative Rick Boucher (Democrat, Virginia). The bill would provide the International Trade Commission with the authority to exclude foreign products made using a host cell, DNA sequence, or vector patented in the United States, closing what the bill's sponsors believe to be an unfair legal loophole.

Genetics Institute would be affected by the legislation, as it would prevent the importation into the United States of its EPO product, which is produced in Japan by its licensee, Chugai Pharmaceuticals.

Godown was both "surprised and saddened" by the news and says that "this dispute arises out of a difference of opinion concerning what is best for the long-term interests of the development of the biotechnology industry". Diane Gershon 